\title{
Life of the Blessed Virgin Mary
}

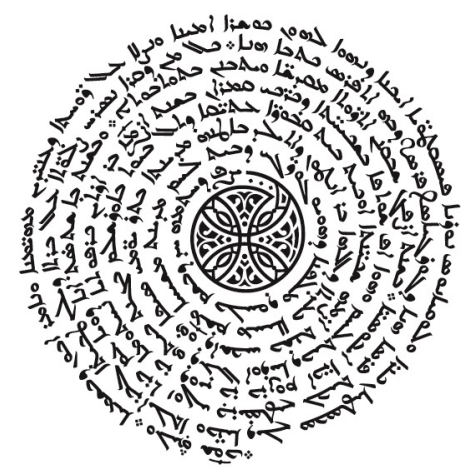




\section{Texts from Christian Late Antiquity}

68

Series Editor

George Anton Kiraz

TeCLA (Texts from Christian Late Antiquity) is a series presenting ancient Christian texts both in their original languages and with accompanying contemporary English translations. 


\section{Life of the Blessed Virgin Mary}

Translated from Syriac to Malayalam by

Rev. Fr. Kuriyakos

Pallikkapparambil (1926 AD)

Translated from

Malayalam to English by

Sarah Knight
With a Foreword

by

Sebastian P. Brock

\footnotetext{
Gorgias 
Gorgias Press LLC, 954 River Road, Piscataway, NJ, 08854, USA

www.gorgiaspress.com

2021 Copyright (C) by Gorgias Press LLC

All rights reserved under International and Pan-American Copyright Conventions. No part of this publication may be reproduced, stored in a retrieval system or transmitted in any form or by any means, electronic, mechanical, photocopying, recording, scanning or otherwise without the prior written permission of Gorgias Press LLC.

2021

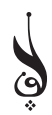

ISBN 978-1-4632-4355-5

ISSN 1935-6846

\section{Library of Congress Cataloging-in-Publication} Data

A Cataloging-in-Publication Record is available at the Library of Congress.

Printed in the United States of America 
To the memory of my beloved mother Elizabeth Abraham of Illikalam-family, Kumarakom, Kerala, India 
